\title{
Pharmacological Activation of Kainate Receptors Drives Endocannabinoid Mobilization
}

\author{
Joana Lourenço, ${ }^{1,2,3,4}$ Isabel Matias, ${ }^{1,4}$ Giovanni Marsicano, ${ }^{1,4 \star}$ and Christophe Mulle ${ }^{3,4 \star}$ \\ ${ }^{1}$ INSERM U862 NeuroCentre Magendie, "Endocannabinoids and Neuroadaptation," 33077 Bordeaux, France, ${ }^{2}$ PhD Programme in Experimental Biology \\ and Biomedicine, Center for Neuroscience and Cell Biology, University of Coimbra, 3004-504 Coimbra, Portugal, ${ }^{3}$ Laboratoire "Physiologie Cellulaire de la \\ Synapse" CNRS UMR 5091, 33077 Bordeaux, France, and "University of Bordeaux, 33077 Bordeaux, France
}

Activation of both presynaptic metabotropic cannabinoid type 1 receptors $\left(\mathrm{CB}_{1} \mathrm{~s}\right)$ and ionotropic kainate receptors (KARs) can efficiently modulate GABA release at many synapses of the CNS. The inhibitory effect of kainic acid (KA) has been ascribed to metabotropic actions, and KAR-induced release of secondary neuromodulatory agents may partly mediate these actions. Here, we investigated the involvement of the endocannabinoid system in the modulation of GABAergic synaptic transmission by pharmacological activation of KARs with KA in CA1 pyramidal neurons of the mouse hippocampus. We show that the depression of GABAergic synaptic transmission induced by KA $(3 \mu \mathrm{M})$ is strongly inhibited by the simultaneous blockade of $\mathrm{CB}_{1}$ and $\mathrm{GABA}_{\mathrm{B}}$ receptors with SR141716A (5 $\left.\mu \mathrm{M}\right)$ and CGP55845 (5 $\left.\mu \mathrm{M}\right)$, respectively. KA induces a calcium-dependent mobilization of the endocannabinoid anandamide (AEA) by activation of GluK2containing KARs in postsynaptic pyramidal neurons. Consistently, the effect of KA is prolonged by the inhibitor of AEA degradation URB597 $(1 \mu \mathrm{M})$ in a $\mathrm{CB}_{1}$-dependent manner, but it is not altered by blockade of degradation or synthesis of the other main endocannabinoid 2-arachidonoylglycerol (2AG). Hence, our work reveals that the pharmacological activation of KARs leads to the stimulation of secondary metabotropic signaling systems. In addition, these data further underline the profound mechanistic differences between exogenous and endogenous activation of KARs in the hippocampus.

\section{Introduction}

GABA release from presynaptic terminals is under the control of several neurotransmitters and neuromodulators, including endocannabinoid signaling lipids [eCBs (Kano et al., 2009)]. Together with the metabotropic cannabinoid receptors and the machinery for their synthesis and degradation, eCBs form the endocannabinoid system [ECS (Piomelli, 2003)]. The activation of presynaptic cannabinoid receptors $\left(\mathrm{CB}_{1}\right)$ by retrograde mobilization of eCBs decreases GABA release throughout the CNS (Alger, 2002; Kano et al., 2009). Endocannabinoid mobilization can be triggered by postsynaptic activation of glutamate receptors such as metabotropic group I and ionotropic NMDA receptors (Alger, 2002).

Kainate receptors (KARs) are homomeric or heteromeric ionotropic receptors assembled in tetramers from five different subunits [GluK1-GluK5 (Pinheiro and Mulle, 2006)]. KARs modulate GABAergic synaptic transmission in the CNS (Lerma, 2006; Pinheiro and Mulle, 2006). Activation of KARs by exogenous kainate (KA) decreases evoked IPSCs (eIPSCs) (Fisher and

\footnotetext{
Received July 7, 2010; revised Dec. 21, 2010; accepted Dec. 30, 2010

This work was supported by AVENIR/INSERM (G.M.), Agence Nationale de la Recherche (ANR-06-NEUR-043-01, G.M.;ANR-05-NEUR-033-01, C.M.), Conseil Régional d'Aquitaine (G.M., C.M.), Fundação para a Ciência e Tecnologia, Portugal and Université Bordeaux (J.L.), Fondation pour la Recherche Medicale (G.M.), European Commission Health Grant REPROBESITY (FPVII-223713, G.M.), CNRS (C.M.), and European Research Council (ERC-2010-StG-260515, G.M.). We thank the personnel of the Animal Facility and of the Genotyping Facility of the NeuroCentre Magendie and Noelle Grosjean for mouse breeding and genotyping; and Mario Carta and Nelson Rebola for comments.

*G.M. and C.M. share senior authorship.

Correspondence should be addressed to either Giovanni Marsicano or Christophe Mulle at the above addresses. E-mail: giovanni.marsicano@inserm.fr or mulle@u-bordeaux2.fr.

DOI:10.1523/JNEUROSCI.3512-10.2011

Copyright $\odot 2011$ the authors $\quad 0270-6474 / 11 / 313243-06 \$ 15.00 / 0$
}

Alger, 1984; Cossart et al., 1998; Frerking et al., 1998; RodríguezMoreno and Lerma, 1998; Bureau et al., 1999; Jiang et al., 2001). Inhibition of eIPSCs by KA was suggested to rely on a noncanonical coupling of KARs to G-protein-dependent signaling (RodríguezMoreno and Lerma, 1998). However, the exact mechanisms through which KARs inhibit evoked GABA release are still debated. A direct biochemical interaction between presynaptic KARs and G-proteins remains to be definitely proven, although coupling between KARs and Gi/Go proteins has been suggested in rat hippocampal membranes (Cunha et al., 2000). The depressing effects of KARs may also result from indirect activation of metabotropic signaling systems (Frerking et al., 1999; Chergui et al., 2000).

Strong evidence points to a cross talk between the ECS and activation of KARs. High doses of KA increase eCB levels in neurons (Di Marzo et al., 1994; Cadas et al., 1996). Furthermore, the ECS plays a neuroprotective role against neurotoxicity and epileptiform seizures induced by KA (Marsicano et al., 2003; Khaspekov et al., 2004; Wettschureck et al., 2006). Finally, activation of presynaptic KARs by endogenous glutamate is necessary for a new form of ECS-dependent short-term synaptic depression [traininduced depression of inhibition, $t-D i$ (Lourenço et al., 2010)].t-Di depends on postsynaptic release of the eCB 2-arachidonoylglycerol (2-AG) through activation of mGluRs, and on the simultaneous activation of presynaptic GluK1-containing KARs and $\mathrm{CB}_{1}$ receptors. However, the exogenous administration of KA might trigger different mechanisms as compared to endogenous release of glutamate acting at KARs. Here, we investigated the involvement of the ECS in the decrease of eIPSCs induced by pharmacological activation of KARs by KA. 


\section{Materials and Methods}

Animals. Experiments followed standard international laws (European Community Directive 86/609/EEC). C57BL/6 mice were from Janvier (France) or were bred at the NeuroCentre Magendie. Mice lacking GluK1 or GluK2 KAR subunits (Mulle et al., 1998, 2000), or $\mathrm{CB}_{1}\left[\mathrm{CB}_{1}{ }^{-1-}\right.$ (Marsicano et al., 2002)] were genotyped as described. For electrophysiology recordings of mutant mice, wild-type littermates were used, whereas measurement of endocannabinoids was performed from C57BL/6 and isogenic GluK2 ${ }^{-1-}$ mice.

Electrophysiology. Parasagittal hippocampal slices (320 $\mu \mathrm{m}$ thick) were obtained from 15to 21-d-old male and female mice as described previously (Lourenço et al., 2010). Whole-cell voltage-clamp recordings were made at room temperature from CA1 pyramidal cells. The intracellular solution contained the following (in mM): $145 \mathrm{CsCl}, 10$ HEPES, 5 EGTA, $2 \mathrm{MgCl}_{2}, 2$ $\mathrm{CaCl}_{2}, 2 \mathrm{Na}_{2} \mathrm{ATP}, 5$ phosphocreatine, and 0.33 $\mathrm{GTP}, \mathrm{pH}$ 7.2. For current-clamp experiments, the pipette solution contained the following (in $\mathrm{mm}$ ): $140 \mathrm{~K}$-gluconate, 10 HEPES, 5 EGTA, 3 $\mathrm{MgCl}_{2}, 10$ phosphocreatine, and 0.2 GTP. Neurons were voltage clamped at $-70 \mathrm{mV}$. D-AP5 (50 $\mu \mathrm{M})$, GYKI53655 (50 $\mu \mathrm{M})$, and CGP55845 $(5 \mu \mathrm{M})$ were present in the superfusion media, unless otherwise indicated. The access resistance of the cells was $<20 \mathrm{M} \Omega$, and recordings were discarded from analysis if the resistance changed by $>20 \%$ over the course of the experiment. Recordings were made using an EPC 9.0 or an EPC 10.0 amplifier (HEKA Elektronik) and were filtered at $0.5-1 \mathrm{kHz}$, digitized at $1-5 \mathrm{kHz}$, and analyzed with IGORPRO 5.0 (Wavemetrics). IPSCs were evoked every $10 \mathrm{~s}$ using a glass pipette filled with a HEPES-based solution positioned in the stratum radiatum, $100 \mu \mathrm{m}$ from CA1 pyramidal cell layer. The presence of $\mathrm{CB}_{1}$-positive inhibitory contacts was always checked by a protocol of depolarization-induced suppression of inhibition [DSI, $5 \mathrm{~s}$ depolarization to $0 \mathrm{mV}$ (Lourenço et al., 2010)]. The t-Di protocol was as described previously (Lourenço et al., 2010). In the experiments involving bath application of $\mathrm{CB}_{1}$ receptor related compounds, the perfusion system was washed before starting the experiments with ACSF containing 0.1\% BSA (fatty acid free), and cannabinoid drugs were preincubated for 45-60 min. The maximal effect of KA was evaluated comparing the amplitudes of eIPSCs before $(0-150 \mathrm{~s})$ and after KA application (350-550 s). Time course data were collected in all experiments and analyzed.

Measurement of endocannabinoids. Hippocampal slices were obtained as for electrophysiological experiments. After drug treatments, slices were dried on Whatman paper and frozen on dry ice. The extraction, purification, and quantification of eCBs was performed as described previously (Di Marzo et al., 2001; Matias et al., 2006). Briefly, after extraction in chloroform/methanol/Tris-HCl $50 \mathrm{~mm}, \mathrm{pH} 7.5$ (2:1:1, v/v), containing internal deuterated standards, the dried lipid extract was prepurified by open bed chromatography on silica-gel minicolumns eluted with increasing concentrations of methanol. Fractions for arachidonoylethanolamide (anandamide, AEA) and 2-AG measurement were obtained by eluting the column with 9:1 (v/v) chloroform/methanol and were concentrated on an N2 stream evaporator. Samples were subjected to liquid SEM. ${ }^{* *} p<0.01$ ( $t$ test)
B
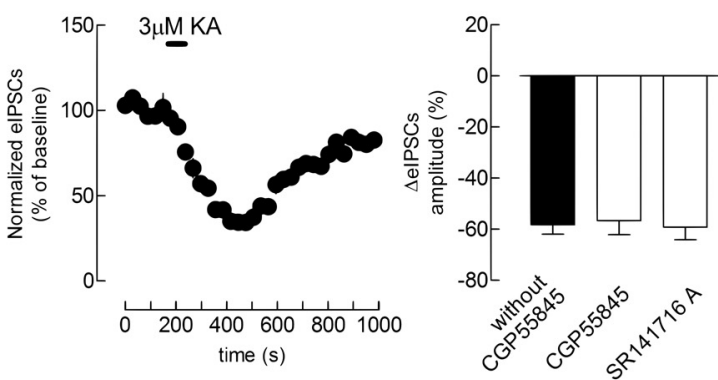

D
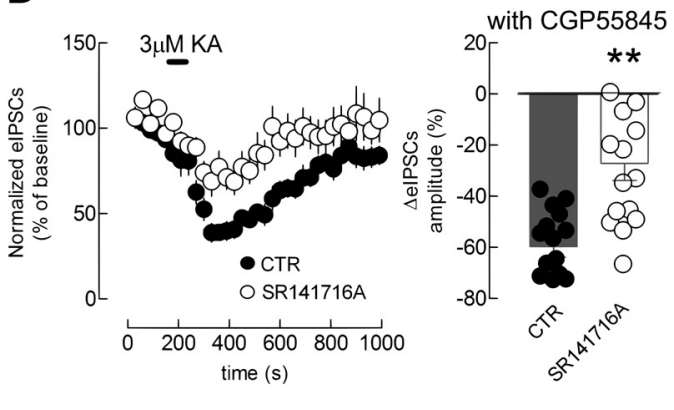

$\mathrm{F}$
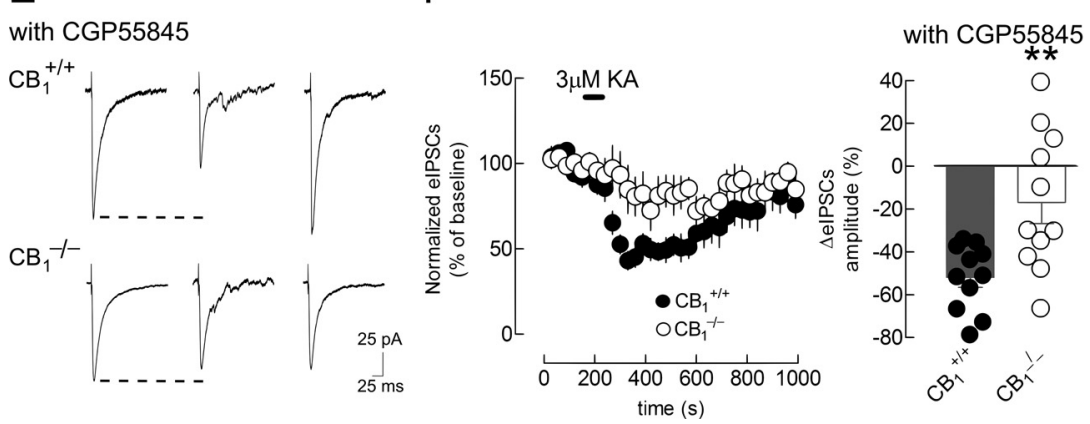

Figure 1. Inhibition of GABAergic synaptic transmission by $K A$ involves $C_{1}$ and $G A B A_{B}$ receptors. $A$, KA depresses elPSCs in pyramidal neurons from $\mathrm{C57BL/6}$ mice (upper traces, control, $(T R)$, as well as in the presence of the $\mathrm{CB}_{1}$ receptor antagonist maximal effect of KA in CTR conditions (black bar) and in the presence of CGP55845 (5 $\mu \mathrm{M})$ or in SR141716A-treated slices (see Fig. $3 D$ for time course data). $\mathbf{C}-\boldsymbol{F}$, KA-induced depression of elPSCs in the presence of (GP55845 $(5 \mu \mathrm{M})$. C, KA-induced depression of CTR and SR141716A-treated slices. Right, Bar graph of the maximal effect of KA in CTR (gray bar, filled circles) and in SR141716Atreated slices (white bar, open circles). $E$, KA depresses elPSCs in pyramidal neurons from $\mathrm{CB}_{1}{ }^{+/+}$(upper traces), but not from $\mathrm{CB}_{1}{ }^{-/-}$mice (lower traces). $\boldsymbol{F}$, Left, Time course of the effect of $\mathrm{KA}$ on elPSC amplitudes in slices from $\mathrm{CB}_{1}{ }^{+/+}$and $\mathrm{CB}_{1}{ }^{-1-}$ littermates. Right, Bar graph of the maximal effect of $\mathrm{KA}$ in slices from $\mathrm{CB}_{1}{ }^{+/+}$and in $\mathrm{CB}_{1}{ }^{-1-}$ mice. Data are shown as mean \pm

chromatography-chemical ionization-tandem mass spectrometric analysis (LC-MS/MS) on a TSQ Quantum triple quadrupole instrument (Thermo-Finnigan) equipped with an APCI source in positive ion mode. The amounts of AEA and 2-AG were determined using a calibration curve and expressed as picomoles per milligram of lipid.

Chemicals. Drugs were from Sigma, Tocris Bioscience, and Cayman. SR141617A was provided by the National Institute of Mental Health Chemical Synthesis and Drug Supply Program. GYKI53655 was synthesized by ABX.

Statistical analysis. Values are presented as mean \pm SEM of $n$ experiments. The effect of bath application of KA on eIPSCs was calculated by comparing the mean amplitude (in picoamperes) of the first 20 eIPSCs after KA application to the mean of the first 15 eIPSCs during baseline ( $\triangle$ eIPSCs). DSI and t-Di were analyzed as described previously (Lourenço et al., 2010). Unpaired $t$ tests were used to compare two independent groups of neurons; one-way ANOVA and two-way ANOVA for 
A
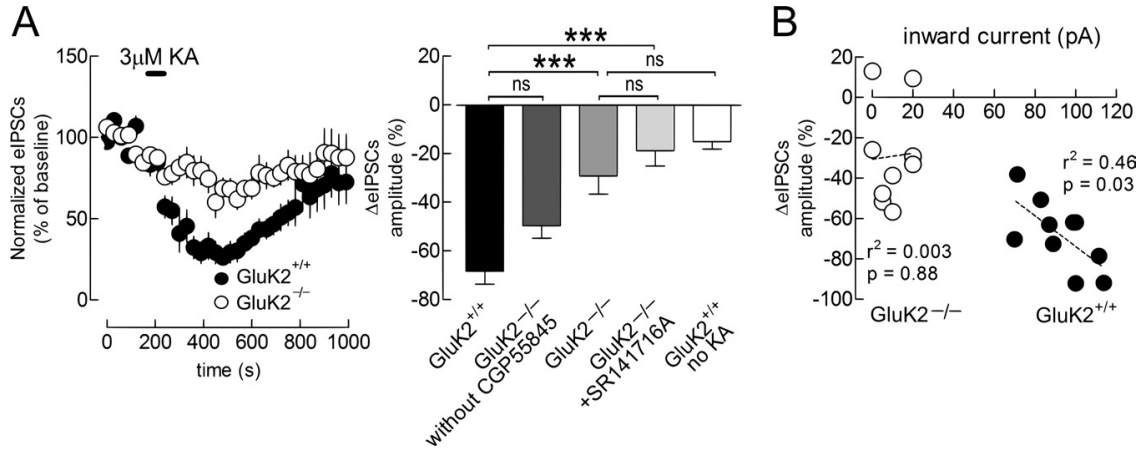

C
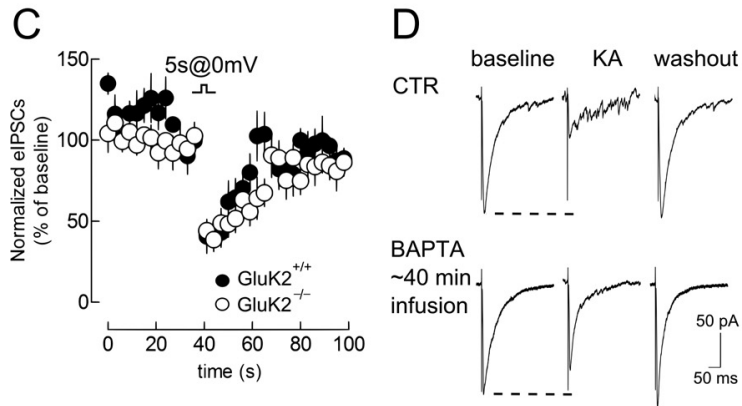

Figure 2. Postsynaptic GluK2-containing KARs mediate KA-induced depression of elPSCs. $\boldsymbol{A}$, Left, Time course of the effect of KA on elPSC amplitudes in slices from GluK2 ${ }^{+1+}$ and GluK2 $2^{-1-}$ mice. Right, Bar graph of the maximal effect of KA in slices from GluK2 ${ }^{+/+}$with CGP55845 (5 $\mu \mathrm{m}$, black bar), from GluK2 ${ }^{-1-}$ without CGP55845 (dark gray bar), from GluK2 ${ }^{-1-}$ with CGP55845 (intermediate gray bar), from GluK2 ${ }^{-1-}$ with (GP55845 and SR141716A (light gray bar), and from GluK2 ${ }^{+/+}$mice with CGP55845 (white bar). $\boldsymbol{B}$, Correlation between the inward current induced by KA application in pyramidal cells from GluK2 ${ }^{+/+}$ and GluK2 $2^{-1-}$ mice and the effect of KA on elPSCs (linear regression). C, Plot of DSI ( 5 s to $0 \mathrm{mV}$ ) in GluK2 ${ }^{+/+}$(filled circles) and GluK2 $^{-1-}$ (open circles) mice. D, KA strongly depresses eIPSC in CTR conditions (upper traces), but not with infusion of BAPTA (20 $\mathrm{mm}$ ) in the patch pipette (lower traces). $\boldsymbol{E}$, Time course of the effect of KA on elPSC amplitudes in slices in CTR (filled circles) and with BAPTA (open circles). Data are shown as mean \pm SEM. ${ }^{* * *} p<0.001$ (Bonferroni's post hoc).

A

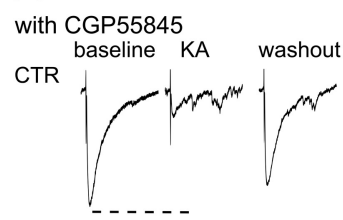

URB597

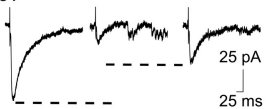

D

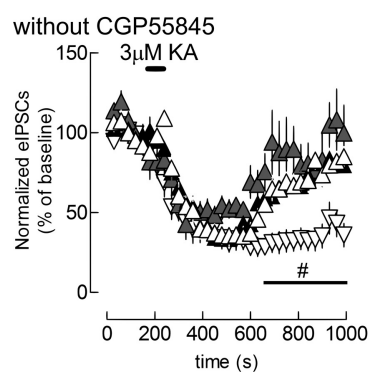

B

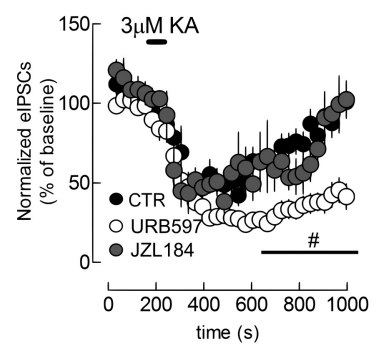

E

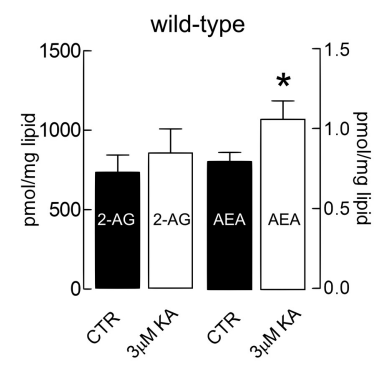

C

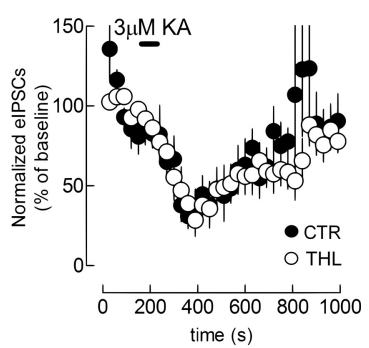

$\mathrm{F}$

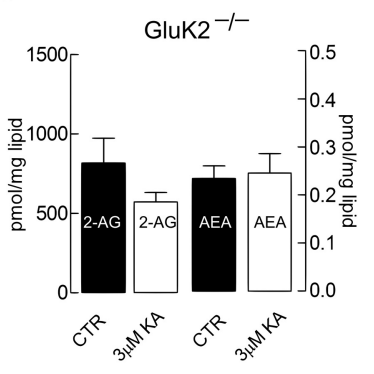

Figure 3. KA induces anandamide mobilization. $A, K A$ depresses elPSCs in (TR conditions (upper traces), and this effect is prolonged by the FAAH inhibitor URB597 (1 $\mu \mathrm{m}$ ) (lower traces). $\boldsymbol{B}$, Time course of the effect of KA on eIPSC amplitudes in CTR conditions (filled circles) and upon treatment with URB597 (open circles) or with the MGL inhibitor (JZL184, $1 \mu \mathrm{M}$, gray circles). $\boldsymbol{C}$ Time course of the effect of KA on elPSC amplitudes in CTR and in slices treated with the DAG lipase inhibitor THL (5 $\mu$ M). D, Time course of the effect of KA on eIPSC amplitudes in the absence of CGP5585, in CTR (filled triangles), with SR141716A alone (open triangles pointing upward), URB597 (open triangles pointing downward) and in SR141716A+ URB584-treated slices (gray triangles). $\boldsymbol{E}, \boldsymbol{F}$, Bar graph of endocannabinoid quantification in CTR conditions or upon bath application of KA in wild-type $(\boldsymbol{E})$ and GluK2 $^{-l-}$ mice $(\boldsymbol{F})$. Data are shown as means \pm SEM. ${ }^{\#} p<0.05$ (Bonferroni's post hoc). ${ }^{*} p<0.05$ ( $t$ test).

repeated measures were used to compare several independent groups and time course data, respectively. When ANOVA resulted in a significant general group effect, Bonferroni's or Dunnett's post hoc tests were applied. A familywise $95 \%$ confidence level was always applied.

\section{Results}

KA-induced depression of GABA release involves $\mathrm{CB}_{1}$ and

$\mathrm{GABA}_{\mathrm{B}}$ receptors

Bath application of $3 \mu \mathrm{M} \mathrm{KA}$ for $100 \mathrm{~s}$ induced a decrease of eIPSCs recorded in CA1 pyramidal cells in control conditions $(-58.3 \pm 3.7 \%, n=19)$ (Fig. $1 A, B)$. This effect was not altered by $\mathrm{CB}_{1}$ blockade by SR141716A $(5 \mu \mathrm{M})(-59.2 \pm 4.8 \%, n=$ 12 , ANOVA, $F_{(2,41)}=0.07, p=0.93$ ) (Fig. $1 A, B)$. Thus, $\mathrm{CB}_{1}$ receptors do not account alone for the KA-dependent decrease of eIPSCs. Similarly, blockade of $\mathrm{GABA}_{\mathrm{B}}$ autoreceptors by CGP55845 (5 $\mu \mathrm{M})$ did not alter the KA effect $(-56.7 \pm$ $5.5 \%, n=13$; ANOVA) (Fig. $1 B$, right). Interestingly, the effect of KA on eIPSCs was strongly reduced by blocking simultaneously $\mathrm{CB}_{1}$ and $\mathrm{GABA}_{\mathrm{B}}$ receptors (CTR plus CGP55845, $-60 \pm 4 \%, n=15$; SR141716A plus CGP55845, -27.5 \pm $6.7 \%, n=15 ; t$ test, $t_{(28)}=4.1, p=$ 0.0003 ) (Fig. 1C,D). We also observed a similar phenomenon using lower doses of KA (500 nм KA; CTR, $-33.05 \pm 4.8 \%$, $n=8$; CGP55845, $-29.43 \pm 6.0 \%, n=8$; SR141716A, $-30.74 \pm 12.0 \%, n=9$; CGP55845 + SR141716A, $19.02 \pm$ $21.7 \%, n=9$; $\operatorname{ANOVA}, F_{(3,30)}=3.47, p=$ 0.02; CTR vs CGP55845 + SR141716A, $p<0.05$, Dunnett's post hoc). Furthermore, upon blockade of $\mathrm{GABA}_{\mathrm{B}}$ receptors, the effect of KA was markedly reduced in slices from $\mathrm{CB}_{1}^{-l-}$ mice $\left(\mathrm{CB}_{1}{ }^{+/+},-51.6 \pm 4.6 \%, n=11 ; \mathrm{CB}_{1}{ }^{-/-}\right.$, $-16.8 \pm 9.8 \%, n=11$; $t$ test, $t_{(20)}=3.2$, $p=0.0044)$ (Fig. 1E,F). Endogenous activation of presynaptic KARs leads to t-Di, a short-term reduction of GABAergic transmission (Min et al., 1999; Lourenço et al., 2010). However, t-Di was independent from $\mathrm{GABA}_{\mathrm{B}}$ receptors ( $\mathrm{t}-\mathrm{Di} \mathrm{CTR}$, $-15 \pm 2 \%, n=12$; t-Di without CGP55845, $-13 \pm 4 \%, n=7$; $t$ test, $\left.t_{(17)}=0.47, p>0.05\right)$. The following experiments were conducted in the presence of the $\mathrm{GABA}_{\mathrm{B}}$ antagonist CGP55845, if not otherwise stated.

\section{GluK2-containing KARs mediate \\ KA-induced depression of \\ GABA release}

Depolarization of the postsynaptic pyramidal cells by KA can potentially induce the retrograde mobilization of eCBs. In the 

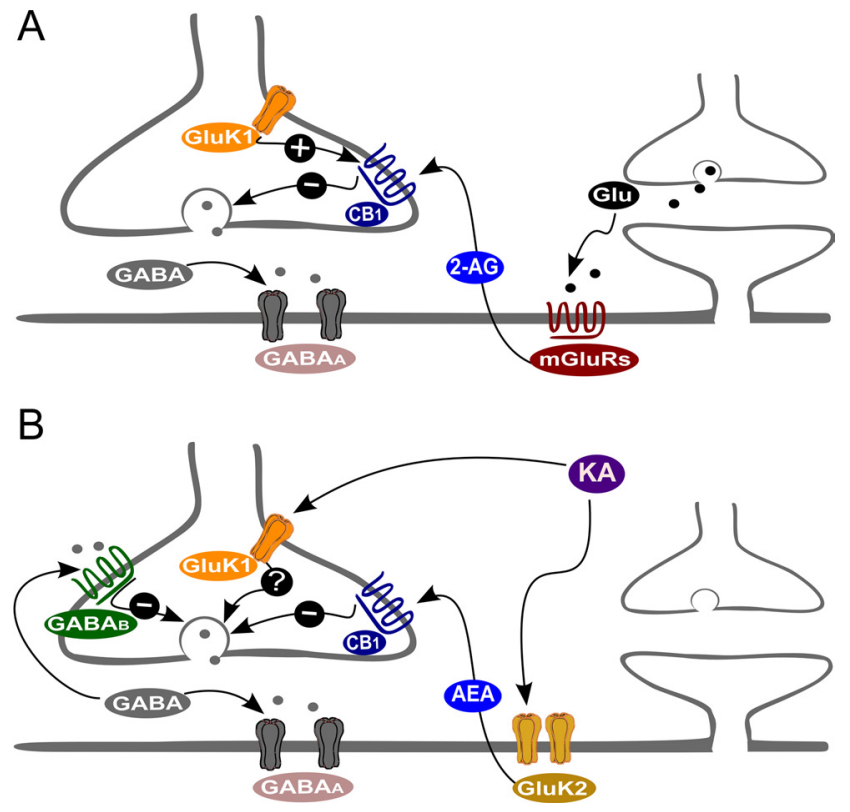

Figure 4. Mechanistic differences between endogenous and exogenous activation of KARs. A, A train stimulation of Schaffer collaterals in hippocampal stratum radiatum, induces a shortterm depression of elPSCs in pyramidal neurons (t-Di) (Lourenço et al., 2010). Glutamate released from Schaffer terminals activates postsynaptic mGluRs mobilizing 2-AG. This ligand will act on $\mathrm{CB}_{1}$ receptors on the $G A B$ Aergic terminal. At the same time, synaptically released glutamate activates GluK1-KARs on GABAergic neurons, gating $C_{1}$ signaling to decrease GABA release. $\boldsymbol{B}$, In the same hippocampal region, exogenous activation of KARs with KA leads to a depression of elPSCS. In these conditions, KA acts on postsynaptic GluK2-containing KARs to mobilize AEA. $C_{1}$ activation upon mobilization of AEA will then inhibit GABA release. Parallel activation of metabotropic $\mathrm{GABA}_{\mathrm{B}}$ receptors can also depress $\mathrm{GABA}$ release.

hippocampus, GluK2 subunit-containing KARs are present in the majority of principal cells and are essential for KA-induced inward currents in CA1 pyramidal cells (Mulle et al., 1998). As previously reported (Bureau et al., 1999), KA induced a depression of eIPSCs in slices from GluK2 ${ }^{+/+}$mice $(-68.1 \pm 5.4 \%, n=$ 10) (Fig. $2 A$ ) as well as in slices from GluK2 $2^{-1-}$ mice in the absence of $\mathrm{GABA}_{\mathrm{B}}$ blockade $(-49.5 \pm 5 \%, n=11$; ANOVA, $F_{(4,38)}=11.44, p>0.05$ vs GluK2 ${ }^{+/+}$) (Fig. $2 A$, right). The presence of CGP55845, however, strongly reduced the KA effect $\left(-29.0 \pm 7.4 \%, n=10\right.$; ANOVA, $p<0.0001$ vs GluK ${ }^{+/+}$) (Fig. $2 A)$. Moreover, we did not observe any further effect of SR141716A $(-18.0 \pm 6.3 \%, n=9$; ANOVA, $p>0.05$, vs GluK2 $^{-/-}$plus CGP55845) (Fig. 2A, right). As expected (Fisahn et al., 2004), the contribution of GluK1 subunit to the KAinduced depression of eIPSCs was negligible in the presence of CGP55845 (supplemental Fig. S1 B,C, available at www. jneurosci.org as supplemental material). Under current-clamp conditions, KA induced a strong membrane depolarization in wild-type pyramidal cells $(22 \pm 6.8 \mathrm{mV}, n=3)$, suggesting that postsynaptic depolarization may contribute to eCBs mobilization. Consistently, the depression of eIPSCs in control mice was proportional to the KA-induced inward currents in the CA1 pyramidal cells (Fig. $2 B$ ), with no distinct inward current in GluK2 $^{-1-}$ mice (Fig. $2 B$; supplemental Fig. S1 $A$, available at www.jneurosci.org as supplemental material). GluK2 ${ }^{-/-}$mice were not impaired in the classical protocol of DSI (Fig. 2C). However, the effect of KA was significantly decreased by infusion of 20 mM BAPTA into the postsynaptic neuron of wild-type mice $(\mathrm{CTR},-57.2 \pm 7.9 \%, n=9$; BAPTA, $-29.4 \pm 9.3 \%, n=9$; $t$ test, $t_{(16)}=2.3, p=0.038$ ) (Fig. $2 D, E$ ). Interestingly, a significant correlation existed between DSI expression and KA-induced de- pression of eIPSCs (supplemental Fig. S2A, available at www. jneurosci.org as supplemental material). Moreover, isolation of $\mathrm{CB}_{1}$-positive inhibitory contacts with the channel blocker of $\mathrm{P} / \mathrm{Q}$ type $\mathrm{Ca}^{2+}$ channels $\omega$-agatoxin IVA (100 nM) (Alger, 2002) did not alter the KA effect (supplemental Fig. S2 B, available at www. jneurosci.org as supplemental material). Thus, GluK2-containing KARs play an important role in the KA-induced depression of eIPSCs by retrograde eCBs mobilization.

\section{KA mobilizes anandamide}

The endocannabinoids 2-AG and AEA are metabolized by complex enzymatic machineries (Piomelli, 2003). The inhibition of AEA degradation by the fatty acid amide hydrolase (FAAH) inhibitor URB597 [1 $\mu \mathrm{M}$ (Kathuria et al., 2003)] significantly prolonged the effect of KA (two-way ANOVA, $F_{(2,957)}=8.65, p=$ 0.001 , drug $\times$ time) (Fig. $3 A, B$ ), while inhibition of 2 -AG degradation with the monoacylglycerol lipase (MGL) inhibitor JZL184 [1 $\mu \mathrm{M}$ (Long et al., 2009)] did not alter the effect of KA (Fig. 3B). Inhibition of 2-AG synthesis by the inhibitor of the DAG lipase tetrahydrolipstatin [THL, $5 \mu \mathrm{M}$ (Bisogno et al., 2006)] did not alter the effect of KA on eIPSCs (two-way ANOVA, $F_{(1,310)}=$ $0.42, p>0.05$, interaction drug $\times$ time) (Fig. $3 C$ ). In the absence of $\mathrm{GABA}_{\mathrm{B}}$ blockade, the effect of URB597 was abolished by SR141716A (two-way ANOVA, $F_{(3,1372)}=6.95, p=0.0005$, interaction drug $\times$ time) (Fig. $3 D)$. Accordingly, bath application of KA to hippocampal slices did not alter the levels of 2-AG (CTR, $790 \pm 109 \mathrm{pmol} / \mathrm{mg}$ lipids; KA, $852 \pm 151 \mathrm{pmol} / \mathrm{mg}$ lipids, $n=5$; $t$ test, $t_{(8)}=0.65, p>0.05$ ) (Fig. $3 E$ ), whereas the levels of AEA were significantly increased after application of KA (CTR, $0.80 \pm$ $0.1 \mathrm{pmol} / \mathrm{mg}$ lipids; KA, $1.1 \pm 0.1 \mathrm{pmol} / \mathrm{mg}$ lipids, $n=5 ; t$ test, $t_{(8)}=2.1, p=0.003$ ) (Fig. 3E). Interestingly, the levels of both $2-\mathrm{AG}$ and AEA remained unaltered after KA application in GluK2 ${ }^{-/-}$mice (Fig. 3F).

\section{Discussion}

Pharmacological application of KA in hippocampal slices results in the simultaneous activation of $\mathrm{GABA}_{\mathrm{B}}$ and $\mathrm{CB}_{1}$ receptors, either of which can lead to the depression of eIPSCs. The participation of presynaptic $\mathrm{GABA}_{\mathrm{B}}$ autoreceptors in this effect of KA was previously suggested (Frerking et al., 1999). Our data indicate that the mechanisms underlying the effects of KA on eIPSCs are more complex than originally suggested (Rodríguez-Moreno and Lerma, 1998). Consistently, triggering of ectopic action potentials in axons was also proposed to mediate this effect (Semyanov and Kullmann, 2001), as well as presynaptic inactivation of interneuronal action potentials (Kang et al., 2004). Interestingly, a recent study demonstrated that low doses of KA can decrease unitary IPSCs only in the cholecystokinin (CCK)-positive subset of interneurons (Daw et al., 2010). Our data indicate that KA leads to the mobilization of the endocannabinoid AEA through the postsynaptic activation of GluK2-containing KARs. However, blockade of both $\mathrm{GABA}_{\mathrm{B}}$ and $\mathrm{CB}_{1}$ receptors does not fully abolish the effect of $\mathrm{KA}$, indicating the possible involvement of other signaling pathways (Rodríguez-Moreno and Lerma, 1998). Nonetheless, our data clearly show that at least part of the metabotropic effect induced by exogenous activation of KARs is due to $\mathrm{CB}_{1}$ and $\mathrm{GABA}_{\mathrm{B}}$ signaling. The application of exogenous KA preferentially mobilizes the eCB AEA in a calcium-dependent manner. Although GluK2 is expressed both in hippocampal pyramidal neurons and in GABAergic interneurons (Mulle et al., 2000), the KA-induced synthesis of AEA appears to occur in postsynaptic pyramidal neurons. 
KARs and the ECS are involved in t-Di, which is induced by endogenous release of glutamate (Lourenço et al., 2010). Interestingly, the present data demonstrate that $\mathrm{t}-\mathrm{Di}$ and exogenous application of $\mathrm{KA}$, although both relying on KARs and $\mathrm{CB}_{1}$, depend on different mechanisms (Fig. 4). t-Di depends on GluK1containing KARs (Lourenço et al., 2010), whereas the KA effects on eIPSCs rely on GluK2-KARs. $\mathrm{GABA}_{B}$ autoreceptors are involved in the pharmacological effects of KA [present results (Frerking et al., 1999)], whereas t-Di occurs independently of $\mathrm{GABA}_{\mathrm{B}}$ signaling. Whereas the mobilization of eCBs in t-Di depends on metabotropic glutamate receptors (mGluRs), the application of KA mobilizes AEA through GluK2-containing KARs. While exogenous applications of KARs agonists (KA as well as L-Glu) (supplemental Fig. S3, available at www.jneurosci.org as supplemental material) preferentially mobilize AEA (present results, supplemental Fig. S3, available at www.jneurosci.org as supplemental material), $\mathrm{t}-\mathrm{Di}$ is mediated by $2-\mathrm{AG}$ (Lourenço et al., 2010). Thus, important differences exist between the signaling pathways triggered by pharmacological versus physiological activation of KARs regarding their interactions with the ECS, likely due to the lack of spatiotemporal selectivity upon exogenous activation of KARs (Fig. 4).

Cannabinoids exhibit antiepileptic properties (Wallace et al., 2001) and modulate pathologic KA-induced synchronization (Mason and Cheer, 2009). Moreover, epileptiform seizures induced by in vivo administration of KA are under the control of the ECS (Marsicano et al., 2003), depending on the specific expression of $\mathrm{CB}_{1}$ receptors in glutamatergic neurons but not in GABAergic neurons (Monory et al., 2006). The present data, by showing that the ECS participates in the KA-induced decrease of GABA release, seem at odds with those results. The most likely explanation for this apparent discrepancy is that KA-induced inhibition of eIPSCs involves both $\mathrm{GABA}_{\mathrm{B}}$ and $\mathrm{CB}_{1}$ receptors. The effects of the ECS on glutamatergic neurons might be predominant in the in vivo model of temporal lobe epilepsy and in the regulation of KA-induced synchronization. In the absence of $\mathrm{CB}_{1}$ receptors in interneurons (Monory et al., 2006), $\mathrm{GABA}_{\mathrm{B}}$ receptors alone might be sufficient to regulate GABAergic transmission induced by the administration of high doses of KA in $v i v o$, in addition to direct effects on presynaptic KARs. However, the regulation of GABAergic synaptic transmission by coactivation of $\mathrm{CB}_{1}$ receptors and $\mathrm{KARs}$ could be relevant for other models of epilepsy. For instance, the modulation of GABA release by the ECS through activation of AMPA/KARs has been implicated in the control of persistent limbic hyperexcitability in several models of juvenile seizures (Chen et al., 2003, 2007).

In conclusion, these results reveal that the activation of the ECS and the stimulation of $\mathrm{GABA}_{\mathrm{B}}$ receptors act in parallel to create the depressing effect of KA on inhibitory hippocampal transmission. These data contribute to a better understanding of the mechanisms of the effects of the neurotoxin KA and provide new insight into the neurocircuitries under the control of KARs in the hippocampus.

\section{References}

Alger BE (2002) Retrograde signaling in the regulation of synaptic transmission: focus on endocannabinoids. Prog Neurobiol 68:247-286.

Bisogno T, Cascio MG, Saha B, Mahadevan A, Urbani P, Minassi A, Appendino G, Saturnino C, Martin B, Razdan R, Di Marzo V (2006) Development of the first potent and specific inhibitors of endocannabinoid biosynthesis. Biochim Biophys Acta 1761:205-212.

Bureau I, Bischoff S, Heinemann SF, Mulle C (1999) Kainate receptormediated responses in the CA1 field of wild-type and GluR6-deficient mice. J Neurosci 19:653-663.
Cadas H, Gaillet S, Beltramo M, Venance L, Piomelli D (1996) Biosynthesis of an endogenous cannabinoid precursor in neurons and its control by calcium and cAMP. J Neurosci 16:3934-3942.

Chen K, Ratzliff A, Hilgenberg L, Gulyás A, Freund TF, Smith M, Dinh TP, Piomelli D, Mackie K, Soltesz I (2003) Long-term plasticity of endocannabinoid signaling induced by developmental febrile seizures. Neuron 39:599-611.

Chen K, Neu A, Howard AL, Földy C, Echegoyen J, Hilgenberg L, Smith M, Mackie K, Soltesz I (2007) Prevention of plasticity of endocannabinoid signaling inhibits persistent limbic hyperexcitability caused by developmental seizures. J Neurosci 27:46-58.

Chergui K, Bouron A, Normand E, Mulle C (2000) Functional GluR6 kainate receptors in the striatum: indirect downregulation of synaptic transmission. J Neurosci 20:2175-2182.

Cossart R, Esclapez M, Hirsch JC, Bernard C, Ben-Ari Y (1998) GluR5 kainate receptor activation in interneurons increases tonic inhibition of pyramidal cells. Nat Neurosci 1:470-478.

Cunha RA, Malva JO, Ribeiro JA (2000) Pertussis toxin prevents presynaptic inhibition by kainate receptors of rat hippocampal [(3)H] GABA release. FEBS Lett 469:159-162.

Daw MI, Pelkey KA, Chittajallu R, McBain CJ (2010) Presynaptic kainate receptor activation preserves asynchronous GABA release despite the reduction in synchronous release from hippocampal cholecystokinin interneurons. J Neurosci 30:11202-11209.

Di Marzo V, Fontana A, Cadas H, Schinelli S, Cimino G, Schwartz JC, Piomelli D (1994) Formation and inactivation of endogenous cannabinoid anandamide in central neurons. Nature 372:686-691.

Di Marzo V, Goparaju SK, Wang L, Liu J, Bátkai S, Járai Z, Fezza F, Miura GI, Palmiter RD, Sugiura T, Kunos G (2001) Leptin-regulated endocannabinoids are involved in maintaining food intake. Nature 410:822-825.

Fisahn A, Contractor A, Traub RD, Buhl EH, Heinemann SF, McBain CJ (2004) Distinct roles for the kainate receptor subunits GluR5 and GluR6 in kainate-induced hippocampal gamma oscillations. J Neurosci 24:9658-9668.

Fisher RS, Alger BE (1984) Electrophysiological mechanisms of kainic acidinduced epileptiform activity in the rat hippocampal slice. J Neurosci 4:1312-1323.

Frerking M, Malenka RC, Nicoll RA (1998) Synaptic activation of kainate receptors on hippocampal interneurons. Nat Neurosci 1:479-486.

Frerking M, Petersen CC, Nicoll RA (1999) Mechanisms underlying kainate receptor-mediated disinhibition in the hippocampus. Proc Natl Acad Sci U S A 96:12917-12922.

Jiang L, Xu J, Nedergaard M, Kang J (2001) A kainate receptor increases the efficacy of GABAergic synapses. Neuron 30:503-513.

Kang N, Jiang L, He W, Xu J, Nedergaard M, Kang J (2004) Presynaptic inactivation of action potentials and postsynaptic inhibition of GABAA currents contribute to KA-induced disinhibition in CA1 pyramidal neurons. J Neurophysiol 92:873-882.

Kano M, Ohno-Shosaku T, Hashimotodani Y, Uchigashima M, Watanabe M (2009) Endocannabinoid-mediated control of synaptic transmission. Physiol Rev 89:309-380.

Kathuria S, Gaetani S, Fegley D, Valiño F, Duranti A, Tontini A, Mor M, Tarzia G, La Rana G, Calignano A, Giustino A, Tattoli M, Palmery M, Cuomo V, Piomelli D (2003) Modulation of anxiety through blockade of anandamide hydrolysis. Nat Med 9:76-81.

Khaspekov LG, Brenz Verca MS, Frumkina LE, Hermann H, Marsicano G, Lutz B (2004) Involvement of brain-derived neurotrophic factor in cannabinoid receptor-dependent protection against excitotoxicity. Eur J Neurosci 19:1691-1698.

Lerma J (2006) Kainate receptor physiology. Curr Opin Pharmacol 6:89-97.

Long JZ, Nomura DK, Cravatt BF (2009) Characterization of monoacylglycerol lipase inhibition reveals differences in central and peripheral endocannabinoid metabolism. Chem Biol 16:744-753.

Lourenço J, Cannich A, Carta M, Coussen F, Mulle C, Marsicano G (2010) Synaptic activation of kainate receptors gates presynaptic $\mathrm{CB}(1)$ signaling at GABAergic synapses. Nat Neurosci 13:197-204.

Marsicano G, Wotjak CT, Azad SC, Bisogno T, Rammes G, Cascio MG, Hermann H, Tang J, Hofmann C, Zieglgänsberger W, Di Marzo V, Lutz B (2002) The endogenous cannabinoid system controls extinction of aversive memories. Nature 418:530-534.

Marsicano G, Goodenough S, Monory K, Hermann H, Eder M, Cannich A, 
Azad SC, Cascio MG, Gutiérrez SO, van der Stelt M, López-Rodriguez ML, Casanova E, Schütz G, Zieglgänsberger W, Di Marzo V, Behl C, Lutz B (2003) CB1 cannabinoid receptors and on-demand defense against excitotoxicity. Science 302:84-88.

Mason R, Cheer JF (2009) Cannabinoid receptor activation reverses kainate-induced synchronized population burst firing in rat hippocampus. Front Integr Neurosci 3:13.

Matias I, Wang JW, Moriello AS, Nieves A, Woodward DF, Di Marzo V (2006) Changes in endocannabinoid and palmitoylethanolamide levels in eye tissues of patients with diabetic retinopathy and age-related macular degeneration. Prostaglandins Leukot Essent Fatty Acids 75:413-418.

Min MY, Melyan Z, Kullmann DM (1999) Synaptically released glutamate reduces gamma-aminobutyric acid (GABA)ergic inhibition in the hippocampus via kainate receptors. Proc Natl Acad Sci U S A 96:9932-9937.

Monory K, Massa F, Egertová M, Eder M, Blaudzun H, Westenbroek R, Kelsch W, Jacob W, Marsch R, Ekker M, Long J, Rubenstein JL, Goebbels S, Nave KA, During M, Klugmann M, Wölfel B, Dodt HU, Zieglgänsberger W, Wotjak CT, et al. (2006) The endocannabinoid system controls key epileptogenic circuits in the hippocampus. Neuron 51:455-466.

Mulle C, Sailer A, Pérez-Otaño I, Dickinson-Anson H, Castillo PE, Bureau I, Maron C, Gage FH, Mann JR, Bettler B, Heinemann SF (1998) Altered synaptic physiology and reduced susceptibility to kainate-induced seizures in GluR6-deficient mice. Nature 392:601-605.

Mulle C, Sailer A, Swanson GT, Brana C, O’Gorman S, Bettler B, Heinemann SF (2000) Subunit composition of kainate receptors in hippocampal interneurons. Neuron 28:475-484.

Pinheiro P, Mulle C (2006) Kainate receptors. Cell Tissue Res 326:457-482.

Piomelli D (2003) The molecular logic of endocannabinoid signalling. Nat Rev Neurosci 4:873-884.

Rodríguez-Moreno A, Lerma J (1998) Kainate receptor modulation of GABA release involves a metabotropic function. Neuron 20: 1211-1218.

Semyanov A, Kullmann DM (2001) Kainate receptor-dependent axonal depolarization and action potential initiation in interneurons. Nat Neurosci 4:718-723.

Wallace MJ, Wiley JL, Martin BR, DeLorenzo RJ (2001) Assessment of the role of $\mathrm{CB} 1$ receptors in cannabinoid anticonvulsant effects. Eur J Pharmacol 428:51-57.

Wettschureck N, van der Stelt M, Tsubokawa H, Krestel H, Moers A, Petrosino S, Schütz G, Di Marzo V, Offermanns S (2006) Forebrainspecific inactivation of $\mathrm{Gq} / \mathrm{G} 11$ family $\mathrm{G}$ proteins results in agedependent epilepsy and impaired endocannabinoid formation. Mol Cell Biol 26:5888-5894. 